\title{
Development of Agritourism in the Relationship with Sociocultural Dynamics of Kursk Region of Russia
}

\author{
Angelina Khromova \\ Postgraduate,Department of Philosophy and Sociology, Southwest State University \\ Email: iomeni@mail.ru

\section{Ekaterina Sevtsova} \\ Postgraduate,Department of Philosophy and Sociology, Southwest State University \\ Email: ekaterinasevcova@mail.ru
}

Anna Spitsyna

Ph.D. in Phylosophy, Associate Professor, Department of Civil Law and Criminal law Disciplines, AEI HPE of Kursk Region, Kursk Academy of State and Municipal Service; Email: ilmedv1@yandex.ru

Ilya Medvedev

Doctor of Medicine, Doctor of Biological Sciences, Professor, Department of State and Municipal Administration AEI HPE of Kursk Region, Kursk Academy of State and Municipal Service; Email: ilmedv1@yandex.ru

Michail Cherkashin

Ph.D. in Phylosophy, Associate Professor, Department of State and Municipal Administration AEI HPE of Kursk Region Kursk Academy of State and Municipal Service; Email: ilmedv1@yandex.ru

Doi:10.5901/mjss.2015.v6n6s5p108

Abstract

The aim is to consider the development of agritourism in Kursk Oblast of Russia in the relationship with the sociocultural characteristics of the region. A series of research methods have been applied: bibliographic analysis of the economic and country-study literature and Internet resources; analytical, cartographic and modeling methods; prognostic and comparative analysis methods. The relationship of agritourism and sociocultural dynamics of the region has been analyzed. The basic definitions such as agritourism and sociocultural dynamics have been given. By the example of Kursk Oblast the key points of the implementation of the agritourism product have been identified, taking into account sociocultural characteristics. The efficiency of the development of agritourism in the economic and sociocultural perspective has been indicated.Kursk Oblast is a favorable region for the creation and development of agritourism products. At the same time, it is required that a programme for agritourism be developed and implemented for taking into consideration all positive and negative aspects of the region. The article serves as a trigger for further study of agritourism and for monitoring of sociocultural dynamics of the region.

Keywords: agritourism, agritourism product, sociocultural characteristics of the region, sociocultural efficiency, sociocultural development.

\section{Introduction}

The increased interest in agritourism in the world and in Russia demonstrates that this phenomenon has a great impact on political, economic, social and spiritual spheres of society. However, so far vital problems of social and economic development have been solved in the first place, but agritourism issues have been outside political priorities,which has led to an unspoken but a definite underestimation of the importance of these issues in society.

The experience of regions where agritourism is booming, shows that this type of tourism may bring about positive sociocultural and economic trends (Shalygina et al., 2013). In this regard, the conception of a multifunctional development of rural areas and diversification of productive activities and services in agribusiness is gaining increasing recognition. Its 
essence is the need to ensure appropriate conditions for the development of rural areas and rural lifestyles in several directions. Particular attention is paid to non-productive activities, since agricultural production alone cannot ensure the harmonious development of the environment and wealth for rural residents. An important line of the implementation of this strategy is the development of rural and agricultural tourism. In addition, it increases employment of rural population, provides the growth of labor potential of rural areas and the improvement of rural settlements.

The concept of «agritourism» emerged in the literature in the late XX century; it comes from the Greek word «agros» which means "field", but in compound words it corresponds to the concepts of "land", "agricultural"; and «agrónomos» which indicates the involvement in management in the rural area.

Definition of agricultural and rural tourism (as well as tourism in general) is a sufficiently complex problem, and it is solved in different ways in different countries. All of the concepts found in the literature, are united mainly by the so-called "degree of detail." The broadest interpretation of the concept of "rural tourism" is tourism which is based in rural houses (yards) or farms, or even in the rural area, but it does not include recreation in special recreational areas, such as national parks, forest areas, etc. Simply put, these are almost all of the forms of recreation opportunities in rural areas. This definition is used in Russia as well, although often, there is a mixture of concepts of rural tourism, agritourism and green tourism, despite the fact that the first of them is a much broader concept. The international concept corresponds to the above - it is "tourism based on farms » (farm tourism or farm-based tourism).

We can consider agritourism as part of a broader concept of rural tourism, where rural household (Agriturismo) serves as a base for the tourist. It is on this concept - which is internationally recognized and sufficiently clear - that we rely in our studies. In Russia, as we have already pointed out, the concept or agritourism and rural tourism in general is often associated with the concept of "rural green tourism", ecotourism. Consider their common and distinctive features.

Agritourism has something in common with tourism -- it meets the criteria of ecological compatibility, i.e. contributes to environment protection, conservation of natural monuments, etc. In other countries, offers of farmsteads are often combined with the requirements of ecologically compatible behavior of tourists. But agritourism has another purpose: it offers a stay in the agricultural enterprise (farm), farmsteads (household) and the study of rural life, or just holiday in the scenic area, while ecotourism is focused on the active study of the nature and most often active travel.

Any kind of tourism is a form of active recreation outside the place of permanent residence. Physical, learning, sports and other needs stimulate people to holidaymaking. Agritourism de facto is a concept that emerged as a result of tourism service offers by peasant households or farms. With the development of the tourist movement it has become voluminous, outlining the activities related to service given not only to tourists and villagers. Therefore, the concept of «agritourism» is treated slightly differently by tourists and business entities. For the tourist, agritourism means a tourist activity of the person who intends to become familiar with agricultural production and / or to relax in rural environment.

The idea of agritourism is based on the belief that a peasant farm is the main object that can provide travel services. Having free labor and housing resources combined with their own inexpensive food products and due to the entrepreneurial activity, it can supplement their income. However, practice shows that other business entities are interested in agritourism activities too, namely, various commercial organizations, primarily those in the territories suitable for tourism for their natural and climatic characteristics.

Agritourism can be defined as a kind of rural tourism of learning and entertaining nature associated with the use of private plots_or lands of agricultural enterprises, temporarily not used in the agricultural sector. The principal figure providing operation of these types of tourism and recreation in rural areas is the rural family, which offers housing, food, and familiarizes the tourist with the countryside.

Agritourism provides income not only to peasant households and farms that give services, but also to owners of shops and gas stations, to artisans and other villagers. The so-called avalanche effect emerges and sets the local economic infrastructure in motion. As a result, the income received from tourists help to increase the demand for other services to which tourism may not be related.

We emphasize again that the concepts of "rural tourism" and «agritourism» are not equivalent, although these types of tourism are closely linked. In general, rural tourism, apart from showing the process of crop and livestock producttion and of home processing of products, covers those human activities that pertain to rural way of life, culture and religion. Focusing on agritourism activities without rural tourism is artificial, since individual farms are an essential part of rural areas.

In the European Union the village performs many non-agricultural functions, and the difference between agritourism and rural tourism is essential there. In areas where farming is scattered or fragmented, and the rural community is compact and well-organized it would be more appropriate to use the concept of "rural tourism."

With the development of urbanization processes, the importance of the traditional rural community fades into the background as the role of cities grows. Therefore, in the future, the term «agritourism» will probably be accepted more 
frequently.

Here are the three main features of agritourism that distinguish it from conventional mass tourism.

The first feature is the ability to satisfy the human need to participate in the process of food production, and in the life of a peasant family and the local community. It is difficult to understand such agritourism, but it's quite an ambitious form of tourism. This kind of tourism is of no interest for the bulk of tourists, and only those who want to combine relaxation with the acquisition of new skills are attracted by it.

The second characteristic feature of agritourism, compared with the mass one, is that it is possible to satisfy the people's needs to learn something new in such areas as agricultural production and ethnography. Agritourism creates conditions for familiarizing oneself with peasant life, their culture and customs in the regional dimension.

The third feature of agritourism is the possibility to satisfy emotional needs by a direct contact with hosts and domestic animals, with products of plant and animal processing; to meet the needs of experiencing a rural idyll created by the surrounding atmosphere, silence, background village noise, etc. If agritourism is devoid of cognition component, if it does not support the emotional needs of the person, but is based only on recreation and satisfaction, it does not differ from conventional tourism.

At the same time, agritourism in Russian regions has not fully taken shape yet, and its content requires further reflection. In this context, the aim of this study is to examine the development of agritourism in Kursk Oblast in its relationship with sociocultural characteristics of the region.

\section{Literature Survey}

Agritourism is an expanding sector of tourism business gaining economic and sociocultural significance. Agritourism originated abroad, gradually attracting more and more adherents and fans (Sharpley and Roberts, 2004). Agritourism was supported by various regional studies that showed a revitalizing effect of climatic factors of certain regions on the body (Kutafina and Medvedev, 2015), positively influencing even hereditary pathology (Amelina and Medvedev, 2009). That was closely intertwined with the tourists' acute needs to familiarize themselves with sociocultural features of the regions most favorable for visiting. Nowadays issues of agritourism and sociocultural characteristics at the regional level are in the focus of attention (Kogay et al., 2012). There is a sufficiently great interest to the issues of agritourism and sociocultural dynamics typical of central Russia with its rich black soil and centuries-old traditions of agriculture closely intertwined with sociocultural heritage of the region (Sevtsova and Isaycheva, 2015).

\section{Research Methods}

To effectively analyze the relationship agritourism and sociocultural dynamics, a number of methods have been used. The bibliographic research method allowed us to analyze theoretical aspects of various definitions. The analytical method was used to analyze the sociocultural and economic potential of the region for the development of agritourism. To study the recreational resources of the region, a cartographic method was used. In creating a model project "Farmhouse in "Nightingale Land," the method of modeling was used. Evaluation of the existing agritourism product in Kursk Oblast required the study of the situation in the regions of the Central Federal District of the Russian Federation; for this purpose the method of comparative analysis was applied.

\subsection{Empirical Methods}

A set of general-scientific and sociological methods was used in the research. To summarize and interpret information, methods of comparative and historical analysis were applied, and for conceptualization, the sociocultural approach was used. In the process of collecting empirical materials, content analysis of media and documents, analysis of the data of sociological research and the method of expert evaluations were employed. To reveal the need to create agritourism product, two methods were used: a mass survey, in which residents of the city of Kursk participated, since the main consumers of agritourism products are city residents; and an expert survey in the form of in-depth unstructured interviews of tourism business owners.

\section{Results and Discussion}

It should be noted that in order to arrange effective agritourism business, it is necessary to monitor sociocultural dynamics of the region. There is a need in examining agritourism at a regional level in terms of economic and 
sociocultural dynamics (Kundius, 2011)

The economic efficiency of tourism in Kursk Oblast consists in getting additional income with appropriate taxation from domestic and inbound tourism by providing service to customers.

In the development of an agritourism product a creative approach was applied involving consideration of sociocultural characteristics of the region, in particular Kursk Oblast, taking in account its sociocultural dynamics, i.e. changes that occur in culture and in people under the influence of external and internal forces, which manifests itself in the increase of the existing forms and the emergence of qualitatively new ones (Joseph, 2012).

After analyzing the sociocultural potential of Kursk Oblast, we found out that the region has a relatively favorable geopolitical location, close to the major industrial centers of Russia and Ukraine and has rich cultural heritage that has been evolving over many centuries. A diversified economic complex, availability of electricity, highly qualified personnel, and cultural traditions contribute to the formation of favorable conditions for doing business in agritourism (Kogay et. Al, 2012).

Kursk Oblast is an important agricultural region of the country; it occupies one of the leading places in the production of a number of agricultural products in Russia. With the growth of agricultural production a new economic cluster has formed in the region, that is farming. However, the socio-economic conditions do not fully contribute to the development of farming. Currently, there is a tendency to its reduction accompanied by the decrease of the number of large farms.

It was found that now the bulk of those employed in agriculture are farm owners and their families, who work without hiring employees. Small farms in the region are on the brink of profitability, and it is important for them to develop an associated business, i.e. agritourism (Sevtsova \& Isaycheva, 2015).

Analysis of the current condition of the farms in Kursk Oblast allows a very clear differentiation of areas with different trends in this sphere. The main indicators of the development are the number of farms and the average size of the farm land. In this regard, Kursk Oblast should expect a high return on agritourism. This situation suggests positive dynamics of the development of Kursk Oblast with preservation of cultural heritage of "the nightingale land".

The aim of the project, "Agritourism in the "Nightingale Land" is the development of a business plan of the agritourism product in Kursk Oblast. To achive this goal the following tasks have been solved:

- scientific approaches to the terminology in the sphere of eco-agritourism have been studied;

- various aspects of the development of agritourism have been considered;

- the world trends in the development of agritourism have been taken into account;

- recreational and socio-economic potential of Kursk Oblast for creating an agritourism product has been analyzed; the potential of the farm, LLC "Deira", that will serve as the base for creating the product has been considered in detail;

- a business plan for an agritourism business has been developed on the base of LLC "Deira";

- the effectiveness of this farm has been evaluated, taking into account the sociocultural and economic aspects (profitability and payback of the business project have been calculated).

In the present study, the authors summarize the available experience in this field and offer their vision of an agritourism product that can be created in Kursk Oblast.

The developed project, "Agrotourism in the "Nightingale Land", is determined by the emergence of new legal entities, organizations engaged in tourist activities, as well as by the involvement of residents of the neighboring settlements in the process of giving tourist services.

It relies on the region's sociocultural advantages associated with the development of agritourism and recreation in Kursk Oblast:

- the improved living standards of the population;

- the preserved cultural heritage of the peoples living in the region;

- assistance in the creation and maintenance of tourist attractions

- opportunities for cross-cultural communication and exchanges

- creation of natural and historical-cultural monuments

- creation of an attractive tourism image of the region;

- a sense of pride of the local population for their culture

- the increased number of places of recreation for the population of Kursk Oblast

- $\quad$ promotion of healthy and active leisure in the region (Alikhanova \& Kharchenko, 2012).

The theoretical significance of the study consists in the analysis of the possibilities for creating rural tourism in the 
relationship with the sociocultural dynamics of the region, scientific and theoretical substantiation of organizational and sociological methods of its development in the region and the impact on the sociocultural development of the region.

The practical significance of the study is that the results of it can be used in practical activities of tourism businesses in Kursk Oblast when developing agricultural, agro-ethnographic and cultural tourism programs, as well as in the preparation of materials on the impact of these types of tourism on regional development.

The survey conducted among residents of the city of Kursk confirms the hypothesis that the main consumers of the agritourism product are young families having children - 48\%. 25\% of young people at the age of 18-35 would like to have this kind of recreation together with their friends. Enthusiasts of an active lifestyle (14\%) consider agritourism as a form of recreation, if there are conditions for sports; $13 \%$ of respondents who need the agritourism product are elderly people (Figure 1.)

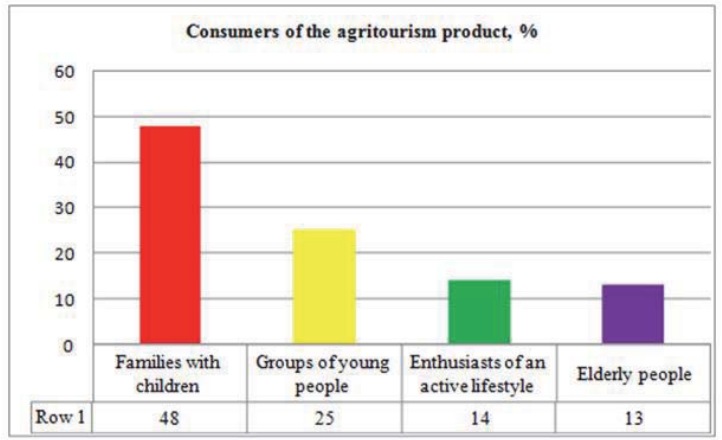

Figure 1. Consumers of the agritourism product

The expert survey of tourism business owners has revealed a general economic trend: if there is demand for the agritourism product, there will be willingness to create an offer in the form of rural tourism. Without appropriate research of consumers, tourism business owners are wary of this tourism product. Anyway, many tourism business owners are willing to create new tourism itineraries, including those connected with rural tourism. The research shows that most of the respondents point to the availability of unique cultural monuments and traditions associated with ethnic and social features of Kursk Oblast; nevertheless, not all of them are included in the tourism iteneraries.

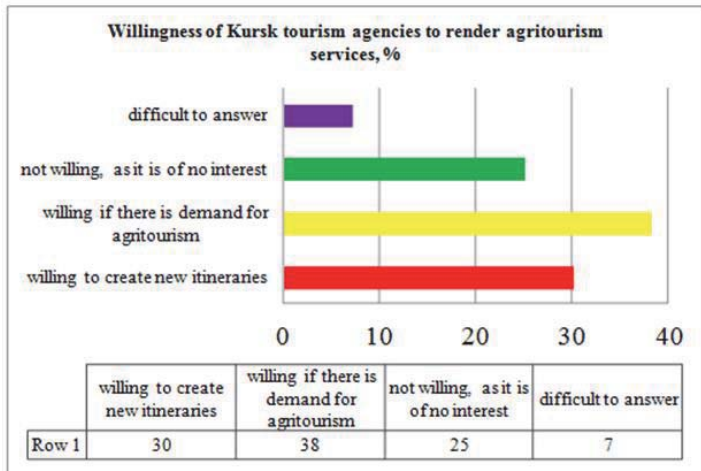

Figure 2. Distribution of the respondents' answers to the question "Are you willing to provide an agritourism service in your agency?"

Kursk Oblast has ample opportunities for the development of agritourism which in one way or another is already used by entrepreneurs in the Russian Federation. This is evidenced by the presence of more than three hundred agritourism farms which are registered in the 'agritourism association'. In the long term, the area of Kursk Oblast may serve as the 
base for creating the agritourism product.

This judgment is based on the following facts:

- Of the 30 unique natural and geological objects in the region not more than 10 are involved in tourism activities.

- 15 tourism itineraries are realized in the region; only 5 of them imply familiarizing people with local sociocultural ethnos and folk artistic crafts. Meanwhile, more than 142 nationalities and ethnic groups live in Kursk region, the most numerous of them are Russians, Ukrainians, Armenians, Belarusians, Tatars, Azerbaijanis, Gypsies, Moldavians. Most of them retain their national customs and traditions, and many of these representatives have their diaspora; therefore, Kursk Oblast is a multinational region, which serves as an additional resource for implementing agritourism

- Kursk Oblast has a great historical and cultural potential which includes numerous archaeological sites. In addition, in the region each municipal district has dozens of historical monuments which are of great interest not only for city tourists but also for local people.

The combination of these facts indicates that there is a potential for developing agritourism in Kursk Oblast. But it should be borne in mind that the areas of the region are very different both in terms of agricultural development and from the viewpoint of their natural, climatic and cultural-historical potential.

To estimate the potential for the development of agritourism in Kursk Oblast, we propose the following indicators: the existence of a unique ethnos and folk artistic crafts; the number of cultural sights in the region; the proportion of agricultural producers in the area in the total number of them in the region.

In general, residents of rural areas, farmers, municipal rural bodies, consumers of a tourism product, regional touroperators and employees of tourism sector should be considered to be the target audience of the project.

\section{Conclusion}

The level of the economic development of rural areas is regarded to be the basic indicator of the economic development of the whole country. At present, the greater part of rural economy of the world is faced with socio-economic problems associated with the inefficient use of natural resources, poor rural infrastructure, low level of well-being of the local population, unemployment and the growing depopulation trend in rural areas. Therefore, the problem of increasing the rural economy is important for many countries in the world as a vital issue of economic prosperity.

The conducted research has shown that creating agritourism products in Kursk region can have a positive effect on the economy and sociocultural environment of the region. In addition, the vector of development in Kursk Oblast is likely to be developed in the line of prosperity of the local economy, and rational and careful use of natural resources, benefiting the population through the provision of stable employment and the development of traditional crafts and folk artistic crafts. In terms of sociocultural dynamics some problems that are quite surmountable, but hindering the development of Kursk Oblast can be traced. This is due to the cyclic character of the sociocultural and economic development of the region. Agritourism, being able to stimulate many processes in Kursk Oblast, can help overcome the difficulties.

\section{References}

Alikhanova, E.V., Kharchenko, K.V. (2012). Formirovaniye programmy razvitiya sel'skogo turizma na territotii munitsipal'nogo raiona [Formation of the development program of the rural tourism on the territory of the municipal district]. Practica munitsipal'nogo upravleniya, 10, 70-76.

Amelina, I.N., Medvedev I.N. (2008). Evaluation of the Dependence of Mutagenesis Intensity on Activity of Nucleolus Organizer Regions of Chromosomes in Aboriginal Population of Kursk Region. Bulletin of Experimental Biology and Medicine, 145(1), 68-71.

Europe in figures. Eurostat Yearbook 2010 // URL: http://epp.eurostat.ec.europa.eu (date of access 18.09.2015)

Joseph, J. (2012). The social in the global. Social theory, governmentality and the global politics. Cambridge, 320.

Kogai, A.A., Kogai, E.A., Pasovets, Yu.M. (2012). Sotsiokul'turnaya dinamika Kurskoy oblasti i vyzovy modernizatsii [Sociocultural dynamics of the Kursk oblast and modernisation challenges]. Sotsoalogitcheskiye issledovaniya, 9, 41-48

Khromova, A.V. (2014). Regional'ny agroturisticheskiy product: ot idei do biznes-plana []. Kursk: "Utchitel", 138.

Kutafina, N.V., Medvedev, I.N. (2015). Platelet aggregation clinically healthy persons of the second coming of age living in the Kursk region. Advances in Gerontology, 28(2), 321-325.

Kundius, V.A. (2011). Agroturizm: problemy i perspektivy razvitiya [Agritourism: problems and development prospects]. Barnaul: Azbuka, 345.

Sevtsova, E.Yu., Isaitcheva, O.A. (2015). Sovremennyye teoretitcheskiye podkhody k izutcheniyu etnosotsialnykh protsessov [Modern 
theoretical approaches to the study of ethno-sociological processes]. Sovremennyye problem nauki i obrazovaniya, 1.

Sharpley, R., Roberts, L. (2004). Rural Tourism-10 Years On. Int. J. Tourism Res, 6, 119-124.

Shalygina, N.P., Selyukov, M.V., Kuratch, E.V. (2013). Brending kak instrument razvitiya sel'skogo turizma [Branding as an instrument of the rural tourism development]. Sovremennyye problemy nauki i obrazovaniya, 3.

Walshok, Mary L. Ph.D. Joshua D. Shapiro, Ph.D. Nathan J. (2013). Owens Unraveling the Cultural and Social Dynamics of Regional Innovation Systems. University of California, San Diego January, 1-28. 